He died peacefully at home in Kingston, Surrey, after suffering from carcinoma of the lung. He will be dearly missed by Barbara, to whom he was married for 40 years, and his children, Hossein, Nassrin and Reza, their partners, Catherine, Matze and Nicola, and his grandchildren, Leila, Kiyan, Jonah and Taraneh.

Ilana Crome \& David Skuse

doi: 10.1192/pb.bp.113.043141

\section{Dr John McCurley}

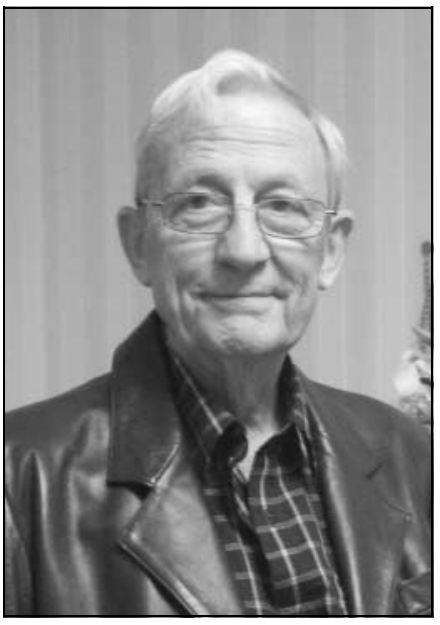

\section{Formerly Psychiatrist and Physician Superintendent}

Dr John McCurley, born on 6 September 1937, was a distinguished psychiatrist who spent virtually all of his professional life in the Glasgow area. Born in Possil, a prize-winning procession through primary school and St Mungo's Academy in Glasgow took him to the medical faculty of Glasgow University at the age of 17 . Not only academically gifted, John also immersed himself in the corporate life of the university. He was on the Board of the Student Union, ran the University International Club and, no mean clarinettist himself, founded, and was President of, the University Jazz Club - bear in mind that this was the era of the Clyde Valley Stompers! Graduating MB ChB in 1961, John decided to enter the field of psychiatric medicine, working with Professor Roger at the Southern General, and at Stobhill and Woodilee Hospitals in the city, before a spell at the Maudsley Hospital in London. It was while at Woodilee that he developed what would become come a lifelong concern for adolescent psychiatry.

At the age of 30 John returned to Scotland as a consultant at Riccartsbar and Dykebar Hospitals, one of the youngest, if not the youngest, consultant in Scotland. He remained at Dykebar, where he became Physician Superintendent, until his retirement. In 1972 he gained his Membership of the Royal College of Psychiatrists and was invited to become a Fellow in 1986. His skill as a forensic psychiatrist took him on many occasions to the High Courts where he gave his professional evidence.

In 1990 John McCurley was appointed as a mental welfare commissioner for Scotland. In this role, protecting the interests of the mentally ill and those with restriction orders in force, he travelled all over the country visiting mental hospitals and prisons.

He was an avid follower of many sports, played golf regularly and served for a spell as President of Clydesdale Cricket Club in Glasgow. He retained his love of jazz but added to that a passion for opera. He possessed a massive collection of CDs, mostly operatic.
In 1966 John married Anna Gemmell, a student teacher, who later in her career became the Conservative MP for Renfrew West and Inverclyde. This marriage ended in 1987. They had one daughter, Honor, who aged only 40, died of a brain tumour in 2011. In later years he enjoyed the companionship of Brenda and they were married on 24 June 2012.

John died on 10 January 2013. A man of real ability, with a quirky sense of humour and wide-ranging interests, John McCurley will be well remembered by colleagues, friends and family alike. His funeral was a private affair, at his own request, but his ashes are being taken up to Crieff in Perthshire, where they will be buried in a woodland cemetery within sight of the Grampian Hills.

$\mathrm{He}$ is survived by Mavourna, his wee Scottie dog, who gave his so much joy in his final year, and by Brenda and her son Andrew.

doi: 10.1192/pb.bp.113.043158

Brenda McGilliard

\section{Dr Peter Kennedy}

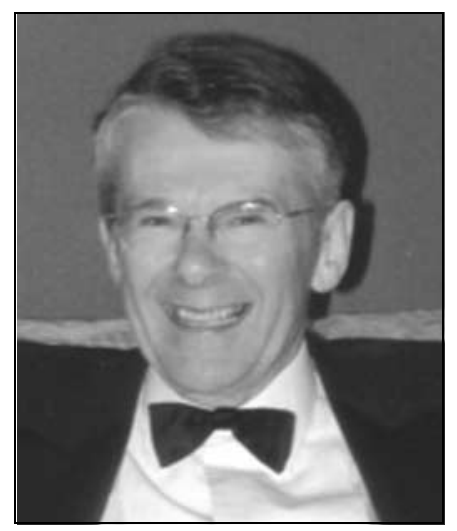

\section{Formerly Psychiatrist and Health Service Manager}

Peter Kennedy was born in Bradford on 31 May 1941. His medical career began at Leeds University, a decision taken almost casually, but which was to have a profound effect on the practice of psychiatry and the management of mental health services in the early 21st century.

Peter began psychiatric training in York in the early 1960s at a time when a series of scandals in large psychiatric hospitals was shaking the National Health Service. He moved on to the Medical Research Council in Edinburgh, where he worked on parasuicide and alcohol misuse and mixed with some of the most significant names in British psychiatry of the 1960 s and 1970s. His teaching ability gained respect and recognition from psychiatrists in training and medical students. His published work was enough to gain him consideration for a Chair, but he was thought to be too young at 36, causing him to reassess his priorities, which lay in shaping services to the needs and choices of patients. He returned to mainstream psychiatry as a consultant in York in 1980 at a time when care was moving from hospital to community, developing services centred on patient priorities. In 1985, Peter reduced clinical time and became manager of the mental health unit where he was able to appoint doctors and nurses to provide treatment outside large expensive hospitals and employ resources more efficiently. His particular skill was listening; he recognised the legitimacy of concern about change, leading by example and allowing doubters to experience the benefits that can come from such change. This approach to management is accepted as commonplace now but was innovative when Peter developed it. 